\title{
HUBUNGAN ANTARA DUKUNGAN KELUARGA DENGAN KEMAMPUAN PERAWATAN DIRI (SELF-CARE) PADA PASIEN PASCA STROKE DI RSUD PIRNGADI KOTA MEDAN
}

\author{
Patimah Sari Siregar ${ }^{1}$, Elis Anggeria ${ }^{2}$, Libertina Laoli ${ }^{3}$ \\ ${ }^{1,2,3}$ Dosen Fakultas Keperawatan dan Kebidanan UNPRI \\ patimahsari818@gmail.com; elis.anggeria@gmail.com
}

\begin{abstract}
Stroke is a condition of brain experiencing neurodegenerative disorders such as local or global, in sudden emergence, progressive, and fast. Impaired nerve function in stroke caused by circulatory disorders of the brain non-traumatic. Post-stroke patients need support and help the family in the treatment himself. This study aims to determine the relationship between family support with self-care skills in patients with post-stroke. The study design is analytic survey with cross sectional approach. The study populations were 40 people and samples of this study were all post-stroke patients who were undergoing rehabilitation of physiotherapy with drawn by saturated sampling technique. The results showed that $47.5 \%$ of respondents got enough family support, and 55\% of respondents have the ability of self-care with some aid. Based on the test results from Spearman Rank correlation, family support with self-care skills has a correlation coefficient of 0.38 and Sig. (2-tailed) 0.01 , meaning there is a relationship between family support and self-care skills on post-stroke patients in the Royal Prima Hospital Medan. In conclusion, this study shows that family support and self-care skills strongly influence at the level of the patient's recovery. It is hoped that families to be more attentive to the needs and provide optimal support either support of awards/emotional, facilities and support information.
\end{abstract}

Keywords: family support, self-care, stroke

\section{PENDAHULUAN}

Stroke merupakan penyakit pada otak berupa gangguan fungsi syaraf lokal atau global, munculnya mendadak, progresif, dan cepat. gangguan fungsi syaraf pada stroke disebabkan oleh gangguan peredaran darah otak non-traumatik. Gangguan syaraf tersebut menimbulkan gejala antara lain: kelumpuhan wajah atau anggota badan, bicara tidak lancar, bicara tidak jelas (pelo), mungkin perubahan kesadaran, gangguan penglihatan, dan lain-lain memiliki tingkat morbiditas yang tinggi sehingga menyebabkan kecacatan (Riskesdas, 2013).

Stroke menjadi penyebab kematian terbesar setelah penyakit kardiovaskuler dan kanker di negara-negara maju. Data dari World Health Organization (WHO) tahun 2008 jumlah kematian didunia sebanyak 57 juta jiwa dan 6,17 juta jiwa meninggal dunia akibat stroke dengan Proportional Mortality Rate (PMR) sebesar 10,8\% (Berman, 2012). Data International Classification of Disease yang diambil dari National Vital Statistics 
Reports Amerika Serikat untuk tahun 2011 menunjukkan rata-rata kematian akibat stroke adalah $41,4 \%$ dari 100.000 penderita (Irdelia, 2014).

Hasil penelitian Riyadina, (2011) menjelaskan bahwa determinan utama stroke meliputi hipertensi, penyakit jantung koroner, diabetes mellitus dan status ekonomi miskin. Pencegahan penyakit stroke dilakukan dengan peningkatan edukasi (kampanye/ penyuluhan) melalui pengendalian faktor resiko utama yaitu hipertensi, dan pencegahan terjadinya penyakit degeneratif lain yaitu penyakit jantung koroner dan diabetes melitus.

Angka kejadian stroke di Indonesia meningkat dengan pesat. Bahkan saat ini Indonesia merupakan negara dengan jumlah penderita stroke terbesar di Asia, karena berbagai sebab selain penyakit degeneratif, dan terbanyak karena stres [Yayasan Stroke Indonesia (Yastroki, 2012)]. Prevalensi stroke di Indonesia berdasarkan diagnosis tenaga kesehatan sebesar 7 per mil (1.236.825 orang) dan yang terdiagnosis tenaga kesehatan atau gejala sebesar 12,1 per mil (2.137.941). Prevalensi Stroke berdasarkan diagnosis tenaga kesehatan (Nakes) tertinggi di Sulawesi Utara (10,8\%), diikuti DI Yogyakarta (10,3\%), Bangka Belitung dan DKI Jakarta masing-masing 9,7 per mil. Prevalensi Stroke berdasarkan terdiagnosis nakes dan gejala tertinggi terdapat di Sulawesi Selatan (17,9\%o), DI Yogyakarta (16,9\%o), Sulawesi Tengah (16,6\%), diikuti Jawa Timur sebesar 16 per mil (Riskesdas 2013 ; Pusdatin, 2013).

Prevalensi penyakit stroke pada kelompok yang didiagnosis tenaga kesehatan (Nakes) bahwa gejala meningkat seiring dengan bertambahnya umur, tertinggi pada umur $\geq 75$ tahun (43,1\%o dan 67,0\%o). Prevalensi stroke cenderung lebih tinggi pada masyarakat dengan pendidikan rendah baik yang didiagnosis nakes (16,5\%) maupun diagnosis nakes atau gejala (32,8\%). Prevalensi stroke di kota lebih tinggi dari di desa, baik berdasarkan diagnosis nakes $(8,2 \%$ ) maupun berdasarkan diagnosis nakes atau gejala $(12,7 \%)$. Prevalensi lebih tinggi pada masyarakat yang tidak bekerja baik yang didiagnosis nakes $(11,4 \%)$ maupun yang didiagnosis nakes atau gejala (18\%). Prevalensi stroke berdasarkan diagnosis atau gejala lebih tinggi pada kuintil indeks kepemilikan terbawah dan menengah bawah masing masing 13,1 dan 12,6 per mil (Riskesdas, 2013).

Stroke membutuhkan penanganan komprehensif termasuk upaya pemulihan dalam jangka waktu yang lama bahkan sepanjang sisa hidup pasien. 
Oleh karena itu salah satu dari anggota keluarga yang mengalami stroke dan menyebabkan kecacatan sehingga membuat pasien stroke kurang mampu untuk memenuhi kebutuhan perawatan dirinya (Self-care) maka pasien stroke membutuhkan bantuan baik minimal maupun total. Bantuan ini akan diberikan oleh orang yang paling dekat dengan pasien stroke yaitu keluarga. Penderita stroke memerlukan bantuan keluarga dalam memenuhi dan mempertahankan kebutuhan hidu pasien selama menjalani perawatan. Keluarga sangat berperan dalam fase pemulihan sehingga keluarga diharapkan terlibat dalam penanganan penderita sejak awal perawatan, kemunduran fisik akibat stroke dapat menyebabkan kemunduran perawatan diri pada pasien itu sendri.

Status sehat dan status sakit para anggota keluarga saling mempengaruhi satu sama lain. Dukungan keluarga sangat penting untuk menjaga dan memaksimalkan pemulihan fisik dan kognitif dalam hasil rehabilitas pada penderita stroke, (Friedman, 1998). Hasil penelitian Wurtiningsih (2012) menyatakan anggota keluarga mampu memberikan berbagai bentuk dukungan kepada penderita stroke yaitu: dukungan informasi/pengetahuan, dukungan instrumental dan dukungan penghargaan dan emosional. Dukungan instrumental dilakukan dengan memberikan terapi rehabilitasi sedangkan dukungan penghargaan diberikan dalam bentuk ucapan terima kasih dan perhatian.

Model perawatan diri menurut Orem (1998) beranggapan bahwa asuhan keperawatan dibutuhkan jika seorang dewasa tidak mampu melaksanakan perawatan diri secara memadai untuk mempertahankan kehidupan, memelihara kesehatan, pulih dari penyakit atau cedera, atau mengatasi efek penyakit atau cedera. Enam konsep utama dalam konsep Orem adalah perawatan diri, agensi perawatan diri, kebutuhan perawatan diri secara terapeutik, defisit perawatan diri, institusi dan sistem keperawatan. Kebutuhan perawatan diri, menurut Orem, meliputi pemeliharaan udara, air/cairan, makanan, proses eliminasi normal, keseimbangan antara aktivitas dan istirahat, keseimbangan antara solitud dan interaksi sosial, pencegahan bahaya bagi kehidupan, fungsi, dan kesejahteraan manusia, serta upaya meningkatkan fungsi dalam perkembangan individu untuk menjadi normal sehingga perawatan diri (self-care) dilakukan dapat mempertahankan kesehatan, baik secara fisik maupun psikologis (Syairi, 2013).

Penelitian menurut (Muhlisin \& Irdawati, 2010) menunjukkan bahwa 
Perawat dalam memberikan asuhan keperawatan klien, mengacu pada teori Selfcare berprinsip terhadap usaha menolong atau membantu pasien individu yang tidak mampu untuk terlibat dalam tindakan self-care yang memerlukan kemandirian dan ambulasi yang terkontrol serta pergerakan manipulatif atau penatalaksanaan medis untuk menahan diri dari aktivitas-aktivitas yang dilakukan. Model keperawatan menurut Orem dikenal dengan model Self-care.

Berdasarkan hasil survei pendahuluan yang di lakukan di RS Royal Prima Medan sebanyak 202 orang. Hal ini menunjukkan bahwa pasien yang mengalami stroke sangat membutuhkan sebuah dukungan keluarga dalam memotivasi pasien agar tidak putus asa, mengingatkan pasien untuk melakukan latihan secara rutin sehingga dapat menimbulkan semangat dari diri pasien itu sendiiri demi tercapainya peningkatan status kesehatan secara optimal dalam memenuhi kebutuhan perawatan dirinya (self-care). Namun kenyataannya keluarga kurang mengetahui bagaimana pemenuhan dan dukungan yang harus dilakukan dan kurangnya pengetahuan akibat perawat di ruangan tersebut tidak memberikan penyuluhan maupun promosi kesehatan untuk menunjang kesembuhan pasien secara optimal. Hal ini membuat peneliti tertarik untuk meneliti mengenai hubungan dukungan keluarga dengan kemampuan perawatan perawatan diri (self-care) pada pasien pasca stroke.

\section{METODE}

Jenis penelitian ini merupakan penelitian survei analitik dengan desain penelitian cross sectional dimana variabel independen dengan variabel dependen diteliti secara bersamaan untuk mengetahui hubungan dukungan keluarga dengan kemampuan perawatan diri (self care) pasien pasca stroke di RS Royal Prima Medan.

Lokasi yang dipilih menjadi tempat penelitian ini adalah di RS Royal Prima Medan. Adapun alasan memilih lokasi tersebut karena jumlah sampel yang dibutuhkan dalam penelitian memenuhi syarat, serta lokasi yang dapat dijangkau sehingga memudahkan peneliti untuk melakukan penelitian dan belum pernah dilakukan penelitian sebelumnya dengan judul yang sama.

Populasi dalam penelitian ini adalah semua pasien pasca stroke di RS Royal Prima Medan. Sampel yang diperoleh oleh peneliti sebanyak 40 responden. Teknik pengambilan sampel dalam penelitian ini ialah Sampling jenuh. Sampel dalam penelitian ini adalah seluruh pasien pasca stroke yang sedang menjalani rehabilitas 
diruangan fisioterapi/rawat inap.

Kuesioner perawatan diri dengan skala

Barthel Index.

Analisis data menggunakan analisa univariat dan bivariat. Analisa univariat dilakukan terhadap setiap variabel yang diteliti dimana masing-masing variabel akan dibuat gambaran distribusi dan persentasi. Data tersebut ditampilkan dalam bentuk tabel frekuensi. Analisa bivariat dilakukan untuk mengetahui hubungan antara variabel independent dengan variabel dependent. Uji hipotesis yang digunakan dalam penelitian ini yaitu statistik Korelasi Rank Spearman dengan tingkat kemaknaan $\alpha=0,05$. Menurut Hidayat dan Istiadah (2011) menyebutkan bahwa Korelasi Rank Spearman digunakan untuk mengukur tingkat atau eratnya hubungan antara dua variabel yang berskala ordinal. Dua variabel yang dimaksud ialah dukungan keluarga dan kemampuan perawatan diri (self-care) pasien pasca stroke.

\section{HASIL DAN PEMBAHASAN}

\section{Hasil}

Hasil penelitian, hubungan dukungan keluarga dengan kemampuan perawatan diri (self-care) pada pasien pasca stroke di RS Royal Prima Medan dengan jumlah responden 40 orang.

\section{Tabel 1.}

Distribusi Frekuensi dan Persentasi Berdasarkan Dukungan Keluarga dan Perawatan Diri (Self-care), Pasien Pasca Stroke di Rumah Sakit Royal Prima $(n=40)$

\begin{tabular}{llcc}
\hline No & Variabel & $\begin{array}{c}\text { Frekuensi } \\
(\boldsymbol{f})\end{array}$ & $\begin{array}{c}\text { Persentase } \\
(\mathbf{\%})\end{array}$ \\
\hline $\mathbf{1}$ & Dukungan & & \\
& Keluarga & & \\
& Baik & 10 & 25,0 \\
& Cukup & 19 & 47,5 \\
& Kurang & 11 & 27,5 \\
\hline & Total & $\mathbf{4 0}$ & $\mathbf{1 0 0 , 0}$ \\
\hline $\mathbf{2}$ & Perawatan & & \\
& Diri (self- & & \\
& care) & & \\
& Mandiri & 6 & 15,0 \\
& Sebagian & 22 & 55,0 \\
& bantuan & & \\
& Maksimal & 12 & 30,0 \\
bantuan & & \\
\hline & Total & $\mathbf{4 0}$ & $\mathbf{1 0 0 , 0}$ \\
\hline
\end{tabular}

Hasil tabel 1 distribusi frekuensi dukungan keluarga dan perawatan diri (self-care) pasien pasca stroke di RS Royal Prima Medan dengan 40 responden, menunjukkan mayoritas responden dukungan keluarga cukup sebanyak 19 orang $(47,5 \%)$, dukungan keluarga kurang sebanyak 11 orang $(27,5 \%)$ dan minoritas dukungan keluarga kurang sebanyak 10 orang $(25 \%)$. Perawatan diri (self-care) mayoritas responden sebagian bantuan sebanyak 22orang (55\%), perawatan diri (self-care) maksimal bantuan sebanyak 12orang (30\%) dan minoritas perawatan diri (self-care) mandiri sebanyak 6 orang $(15 \%)$. 
Tabel 2.

Hubungan Dukungan Keluarga dengan Perawatan Diri (Self-care) Pasien Pasca Stroke di RS Royal Prima Medan $(n=40)$

\begin{tabular}{|c|c|c|c|c|c|c|c|c|c|c|}
\hline \multirow{3}{*}{$\begin{array}{l}\text { Dukungan } \\
\text { Keluarga }\end{array}$} & \multicolumn{4}{|c|}{$\begin{array}{c}\text { Perawatan Diri } \\
\text { (Self-care })\end{array}$} & \multirow{2}{*}{\multicolumn{2}{|c|}{$\begin{array}{c}\text { Maksimal } \\
\text { Bantuan }\end{array}$}} & \multirow{2}{*}{\multicolumn{2}{|c|}{ Total }} & \multirow{3}{*}{$\begin{array}{c}P \\
\text { Value }\end{array}$} & \multirow{3}{*}{$\begin{array}{l}\text { Correlation } \\
\text { coefficient }\end{array}$} \\
\hline & \multicolumn{2}{|c|}{ Mandiri } & \multicolumn{2}{|c|}{$\begin{array}{c}\text { Sebagian } \\
\text { Bantuan }\end{array}$} & & & & & & \\
\hline & $\bar{f}$ & $\%$ & $f$ & $\%$ & $f$ & $\%$ & $\mathrm{~N}$ & $\%$ & & \\
\hline Baik & 2 & $33,3 \%$ & 8 & $36,4 \%$ & 0 & $0,0 \%$ & 10 & $100 \%$ & & \\
\hline Cukup & 2 & $33,3 \%$ & 12 & $54,5 \%$ & 5 & $41,7 \%$ & 19 & $100 \%$ & 0,01 & 0,38 \\
\hline Kurang & 2 & $33,3 \%$ & 2 & $9,1 \%$ & 7 & $58 ., 3 \%$ & 11 & & & \\
\hline
\end{tabular}

Hubungan dukungan keluarga dengan kemampuan perawatan (self-care), menunjukkan dukungan keluarga baik dengan perawatan diri (self-care) mandiri sebanyak 2 orang $(33,3 \%)$, dukungan keluarga baik dengan perawatan diri (selfcare) sebanyak 8 orang $(36,4 \%)$, dukungan keluarga baik dengan kemampuan perawatan diri (selfcare) maksimal bantuan tidak ada. Hubungan dukungan keluarga cukup dengan perawatan diri (self-care) mandiri sebanyak 2 orang $(33,3 \%)$, dukungan keluarga cukup dengan perawatan diri (self-care) sebagian bantuan sebanyak 12 orang $(54,4 \%)$, dukungan keluarga cukup dengan keperawatan diri (self-care) sebanyak 5 orang $(41,7 \%)$. Hubungan dukungan keluarga kurang dengan perawatan diri (self-care) mandiri sebanyak 2 orang $(33,3 \%)$, dukungan keluarga kurang dengan perawatan diri (self-care) sebagian bantuan sebanyak 2 orang $(9,1 \%)$, dukungan keluarga kurang dengan perawatan diri (self-care) maksimal bantuan sebanyak 7 orang (58,3\%). Hasil uji korelasi Rank Spearman, hubungan dukungan keluarga dengan kemampuan perawatan diri (selfcare) dengan tingkat signifikansi $(\alpha<$ $0,05)$ diperoleh correlation coefficient 0.38 dan sig. (2-tailed) 0.01 maka Ho ditolak dan Ha diterima berarti ada hubungan dungan keluarga dengan kemampuan perawatan diri (self-care) pasien pasca stroke di RS Royal Prima Medan.

\section{Pembahasan}

\section{Dukungan Keluarga Pada Pasien Pasca Stroke}

Hasil penelitian menunjukkan bahwa 47.5\% pasien pasca stroke di RS Royal Prima Medan mendapat dukungan keluarga cukup. Dukungan keluarga cukup dikarenakan kurangnya pengetahuan dan kepedulian keluarga 
terhadap pasien pasca stroke dan berbagai faktor-faktor yang mempengaruhi tingkat pengetahuan keluarga seperti dalam mendampingi pasien dalam memenuhi dukungan informasional seperti pemberian informasi, dukungan nyata (waktu, fasilitas dan bantuan materi), dukungan emosional seperti rasa cinta dan mencintai, dan dukungan pengharapan seperti pemberian support kepada pasien.

Kemudian terdapat $27.5 \%$ pasien pasca stroke dengan dukungan keluarga kurang, ini diakibatkan oleh keluarga yang merasa terbebani dengan kondisi kesehatan pasien, kesibukan anggota keluarga lainnya, kurangnya bentuk bantuan yang diberikan kepada pasien (penyediaan alat transportasi untuk mengantar pasien dalam menjalani rehabilitas) sehingga mengakibatkan proses penyembuhan yang lama dan 25\% dukungan keluarga baik, ini terjadi karena sedikitnya kesadaran keluarga dalam memberikan perhatian, semangat, mencari informasi tentang manfaat rehabilitas pasca stroke. Hal ini menyatakan bahwa dukungan keluarga merupakan unsur terpenting dalam membantu individu menyelesaikan masalah kesehatan dan mempercepat penyembuhan pasien tersebut.

Keluarga merupakan sistem pendukung utama yang memberi perawatan langsung pada setiap keadaan sehat ataupun sakit.
Sehingga dengan adanya dukungan keluarga kebutuhan pasien pasca stroke dapat terpenuhi dengan baik melalui dukungan informasional seperti pemberian informasi, dukungan nyata seperti waktu dan bantuan materi, dukungan emosional seperti rasa dicintai, dan dukungan pengaharapan seperti pemberian support.

Hasil penelitian Surono (2013) mengenai dukungan keluarga pada pasien pasca stroke di wilayah kerja puskesmas karanganyer Kabupaten Pekalongan didapatkan lebih dari separuh pasien pasca stroke mempunyai dukungan keluarga baik yaitu 56,8\%, dengan dukungan keluarga sedang sebanyak $27,3 \%$ dan sebagian kecil responden mendapat $15.9 \%$ mendapat dukungan keluarga rendah.

Dukungan keluarga baik dikarenakan adanya keeratan hubungan antar anggota keluarga yang masih terjalin baik, kesadaran dari keluarga yang saling peduli antar anggota keluarga sehingga fungsi keluarga dapat berjalan sebagaimana mestinya.

Dukungan keluarga sedang dan rendah terjadi karena kurang kepedulian antar anggota keluarga dan ketebatasan keluarga dalam memenuhi kebutuhan pasien, pengetahuan dan kondisi ekonomi anggota keluarga yang kurang memadai untuk mempercepat penyembuhan pasien. 
Kemampuan Perawatan Diri (Self Care) Pasien Pasca Stroke

Hasil penelitian dikatakan bahwa hampir setengah pasien stroke memiliki kemampuan perawatan diri dengan sebagian bantuan sebanyak 55\%, kemampuan perawatan diri (self-care) mandiri sebanyak $15 \%$ dan kemampuan perawatan diri maksimal bantuan sebanyak 30\%. Jumlah pasca stroke yang memiliki kemampuan perawatan diri (selfcare) dengan sebagian bantuan lebih banyak daripada kemampuan perawatan diri (self-care) dengan mandiri, tingginya hasil kemampuan perawatan diri dengan sebagian bantuan peneliti berasumsi bahwa hal ini dapat dikarenakan oleh penyakit stroke itu sendiri, lamanya seseorang terkena stroke, rehabilitasi dan dukungan dari keluarga.

Hal ini dapat dilihat dari data umum dimana semua pasien pasca stroke dalam penelitian ini mengalami hemiparesis. Pasca serangan stroke pasien dapat mengalami cacat berupa kelumpuhan anggota gerak, gangguan bicara, proses berpikir, daya ingat dan bentuk-bentuk kecacatan lain sebagai akibat gangguan fungsi otak. Sehingga pada saat sisi tubuh yang mengalami kelumpuhan mereka tidak bisa melakukan aktivitasnya secara mandiri dan membutuhkan sebagian bantuan dari orang lain untuk memenuhi kebutuhan mereka sehari-hari.

Hasil penelitian yang dilakukan oleh Murtutik dan Wigatiningsih (2010) menyatakan bahwa dari 44 responden, pasien yang mengalami ketergantungan total sebanyak 8 orang (18.2\%), sebagian bantuan 14 orang (31.8\%) dan mandiri sebanyak 10 orang (22.8\%), Hal ini terjadi karena pasien yang sedang rehabilitas mengalami gangguan dalam pemenuhan kebutuhan dasar sehari-hari yang cenderung terkena depresi dan sangat membutuhkan dukungan keluarga dalam membantu, memotivasi pasien untuk melakukan aktivitas sehari-hari sehingga pasien tersebut memiliki semangat untuk sembuh dan memiliki kemampuan perawatan diri (self-care) secara mandiri.

\section{Hubungan Dukungan Keluarga dengan Kemampuan Perawatan Diri (Self-care) Pasien Pasca Stroke}

Hasil uji Rank Spearman hubungan dukungan keluarga dengan kemampuan perawatan diri (self-care) dengan tingkat signifikansi $\quad(\alpha<0,05) \quad$ diperoleh correlation coefficient 0,38 dan Sig. (2tailed) 0,01 maka Ho ditolak dan Ha diterima berarti ada hubungan dukungan keluarga dengan kemampuan perawatan diri (self-care) pasien pasca stroke di RS Royal Prima Medan. 
Dukungan keluarga sangat mempengaruhi kemampuan perawatan diri (self-care) pasien pasca stroke. Hal ini terbukti dari hasil penelitian yang telah dilakukan dimana terdapat 40 responden dengan dukungan keluarga baik sebanyak 10 orang (25\%), dukungan keluarga cukup sebanyak 19 orang (47.5\%) dan dukungan keluarga kurang sebanyak 11 orang (27.5\%) dan perawatan diri (self-care) mandiri sebanyak 6 orang (15\%), perawatan diri (self-care) sebagian bantuan sebanyak 22 orang (55\%) dan perawatan diri maksimal bantuan sebanyak 12 orang (30\%).

Pasien pasca stroke yang memiliki dukungan keluargakurang mempunyai kemampuan perawatan diri (self-care) dengan sebagian bantuan, dukungan keluarga cukup mempunyai kemampuan perawatan diri (self-care) dengan maksimal bantuan dan dukungan keluarga baik mempunyai perawatan diri (self-care) dengan mandiri.

Menurut Setiadi (2008) bahwa dukungan keluarga sangat tergantung pada tingkat kesembuhan pasien dalam menjalankan fungsi setiap anggota keluarga dengan baik, semakin baik dukungan keluarga yang diberikan kepada pasien maka fungsi keluarganya akan menimbulkan kesejahteraan pasien, kemunduran dalam melakukan aktivitasnya dan tidak mempercepat penyembuhan pasien selama rehabilitas secara optimal. Dukungan keluarga baik mempengaruhi kemampuan perawatan diri (self-care) pada sesorang yang mengalami keterbatasan dalam pemenuhan kebutuhan, jadi dengan adanya keluarga disamping pasien maka perawatan dirinya dapat meningkatkan proses perkembangan pasien sepanjang siklus hidup berlangsung sehingga perawatan diri sangat efektif (Muhlisin \& Irdawati, 2010).

\section{KESIMPULAN DAN SARAN}

\section{Kesimpulan}

Hasil penelitian dan pemabahasan dapat ditarik kesimpulkan bahwa dukungan keluarga dengan kemampuan perawatan diri (self-care) pasien pasca stroke di RS Royal Prima Medan dengan jumlah responden sebanyak 40 responden, maka diperoleh suatu kesimpulan yaitu: bahwa terdapat gambaran dukungan keluarga dan kemampuan perawatan diri (self-care) pasien pasca stroke, dan terdapat hubungan antara dukungan keluarga dengan kemampuan perawatan diri (self-care) pasien pasca stroke di RS Royal Prima Medan, dimana pasien pasca stroke di RS Royal Prima Medan mendapat dukungan keluarga cukup dan pasien stroke yang melakukan perawatan 
diri dengan sebaagian bantuan dari keluarga maupun orang sekitarnya.

\section{Saran}

\section{Bagi Responden}

Bagi responden diharapkan dapat meningkatkan rasa kepedulian dan memberikan motivasi, dukungan keluarga baik dukungan penghargaan, fasilitas dan informasi terhadap pasien pasca stroke dalam menjalani penyembuhan untuk lebih mandiri dalam memenuhi kebutuhan sehari-hari tanpa bantuan dari keluarga.

\section{Bagi Pelayanan Keperawatan}

Perawat dapat memberikan health education bagi keluarga mengenai stroke, pengobatan, rehabilitas dan perawatan pasien pasca stroke selama dirumah. Perawat juga diharapkan dapat membantu kelurga dan pasien dalam meningkatkan motivasi pasien untuk sembuh secara optimal.

\section{Bagi Peneliti Selanjutnya}

Peneliti selanjutnya diharapkan dapat dijadikan sebagai referensi atau acuan dalam melakukan penelitian dimasa yang akan datang dan menambah pengetahuan/pengalaman dalam meneliti hubungan dukungan keluarga dengan perawatan diri (selfcare) pasien pasca stroke dengan metode pengumpulan data yang berbeda yaitu partisipatif observasional.

\section{DAFTAR PUSTAKA}

Berman, dkk. (2013). Karakteristik Penderita Stroke Haemoragik Yang dirawat Inap di RSUP H. Adam Malik Medan Tahun 2012. http://download.portalgaruda.org/articl e.php?

IDI (Continung Medical Education). (2011). Stroke: Gejala dan Penatalaksanaan. www.kalbemed.com/Portals/6/1_05_18 5Strokegejalapenatalaksanaan.pdf

Hidayat, A,. (2011). Pengantar Konsep Dasar Keperawatan. Jakarta: Salemba Medika.

Irdelia, R, dkk. (2014). Profil Faktor Risiko Yang Dapat Dimodifikasi pada Kasus Stroke Berulang di RSUD Arifin Achmad Provinsi Riau. http://jom.unri.ac.id/index.php/JOMFD OK/article/view/2871

Riset Kesehatan Dasar (Riskesdas). (2013). Badan Penelitian dan Pengembangan Kesehatan. Jakarta: Departemen Kesehatan Republik Indonesia.

Setiadi. (2008). Keperawatan Keluarga. Yogyakarta: Graha Ilmu.

Syairi, A. (2013). Tingkat Pengetahuan Keluarga Pasien Tentang Self-Care (Perawatan Diri) Pada Anggota Keluarga Yang Mengalami Stroke Di RSU Kabupaten Tangerang Tahun 2013. http://repository.uinjkt.ac.id/ dspace/bitstream/123456789/25474/1/ ABU\%20SYAIRI-FKIK.pdf

Wurtiningsih, B. (2012). Dukungan Keluarga Pada Pasien Stroke di Ruang Saraf RSUP Dr. Kariani Semarang. www.medicahospitalia.rskariadi.co.id/i ndex.php/mh/article/view/42

Yastroki (Yayasan Stroke Indonesia). (2012). Gerakan Nasional Orang Tua Asuh. http://www.yastroki.com/. 